\title{
"Um desejo infinito de vencer": o protagonismo negro no pós-abolição
}

Petrônio Domingues

\section{RESUMO}

Ultimamente, diversos estudos têm explorado o tema do protagonismo negro em Santa Catarina no período posterior à abolição da escravatura. Esses trabalhos têm analisado personagens, agenciamentos políticos, conexóes sociais, fluxos culturais e interlocuçóes raciais. O objetivo deste artigo é apresentar um balanço inicial dessa produção acadêmica e, ao mesmo tempo, apontar questóes, discutir problemas e identificar os desafios dessa nova área de pesquisa.

Palavras-chave: protagonismo negro; historiografia brasileira; pós-abolição; Santa Catarina; Brasil.

\begin{abstract}
Lately, several studies have explored the role of black people in Santa Catarina in the period after emancipation. These works have analyzed characters, policy actions, social connections, cultural streams and racial dialogues. The aim of this paper is to present an initial inquiry about this academic out put and at the same time, to point out questions, discuss problems and identify the challenges of this new area of research.
\end{abstract}

Keywords: black protagonism; Brazilian historiography; post-abolition; State of Santa Catarina; Brazil. 
...sem que lhes faltem sonhos, sem que lhes mingüe um desejo infinito de vencer, de realizar, de escalar, de conhecer, há, na planicie, e no sopé da montanha, olhos no cume inatingivel, uma legiäo de vencidos...

Maria da Ilha. Farrapos de ideias, 1937.

Era o ano de 1915. No âmbito da conjuntura externa, a Primeira Guerra Mundial começava a aterrorizar vários países europeus e mobilizava a atenção da opinião pública internacional. No plano interno, o processo de reformas urbanas, o alvissareiro desenvolvimento industrial, as inovaçóes científico-tecnológicas, o projeto de modernização, a atmosfera de nacionalismo contagiava coraçóes e mentes na Belle Époque tropical. Em meio a tudo isso, na cidade de Florianópolis, capital de Santa Catarina, dois poetas negros, Ildefonso Juvenal, com cerca de 21 anos, e Trajano Margarida, beirando os 26, além do amigo Astrogildo Campos, sentiram a necessidade não só de compartilhar seus sonhos e esperanças, como também de vislumbrar o levantamento social, cultural, intelectual e moral dos homens negros. Decidiram comemorar a data da abolição da escravatura, de forma civilizada e cidadã. Para tanto, fundaram a Associação dos Homens de Cor e organizaram um grande evento no Teatro Álvaro de Carvalho, reunindo negros e brancos, homens e mulheres, autoridades públicas, representantes da imprensa e de outras associaçóes da sociedade civil de Florianópolis. Tendo como mote a memória da escravidão, o evento consistiu na apresentação de recitais de poesias, em performances artístico-musicais e discursos cívicos. Muitos dos presentes se sensibilizaram ao ouvir a canção "Liberdade", com letra de autoria de Trajano e melodia do maestro Pendo, e o poema "Vozes d'África”, de Castro Alves, o legendário poeta abolicionista. O evento cívico-literário-musical terminou com um "belo" hino à liberdade, cantado por um grupo de meninas. Todas trajadas de branco, traziam "a tiracolo largas faixas de seda com as cores nacionais e com uma apoteose à raça negra, protegida pela república que lhe apontava o luminoso caminho da liberdade" ${ }^{1}$.

Era o ano de 1918. Em Lages, cidade do interior de Santa Catarina, Joaquim Pinto de Oliveira, um negro, pedreiro e "pessoa de bem", decide lançar a ideia de um clube, ou centro cívico, onde homens e mulheres negros pudessem se reunir para divertirem-se, confraternizarem, exporem suas ideias, ajudarem-se mutuamente e contribuírem para o sentimento de comunhão nacional. Sua proposta foi socializada e apoiada por outros negros da cidade que, em conjunto, marcaram as primeiras reunióes na sede da banda Lira Lageana, para discutirem os encaminhamentos dessa "magnânima" empreitada. Depois de ampla e produtiva discussão, Joaquim Pinto de Oliveira e seus "irmãos de cor" fundaram um Centro Cívico, no dia 22 de setembro de 1918. Em clima de esperança e entusiasmo, deram-lhe o nome de Cruz e Souza, em homenagem ao célebre poeta afro-catarinense ${ }^{2}$; definiram o estatuto e elegeram a primeira diretoria e conselho fiscal dessa que é considerada a primeira associação cívica criada por e para negros no interior do Estado ${ }^{3}$. Dois meses depois, na noite estrelada de 22 de novembro de 1918, encontravam-se no Teatro Municipal da cidade diversos políticos, autoridades municipais, jornalistas, representantes das associaçóes da sociedade civil e curiosos, para participarem da cerimônia comemorativa de posse da primeira diretoria do Centro Cívico Cruz e Souza. Num ambiente de confraternizaçáo, expectativa, formalidade e civismo, tal solenidade ocorreu no bojo das festividades alusivas ao Dia da Bandeira ${ }^{4}$.

Despretensioso, este breve relato aborda a fundação de duas agremiações dos "homens de cor", cujas histórias são uma amostra sintomática do sinuoso e complexo protagonismo negro no Brasil Meridional no pós-emancipação. Antes, porém, que o leitor se pergunte qual foi a trajetória da Associação dos Homens de Cor e do Centro Cívico Cruz e Souza, convém explicar que esse artigo pretende examinar, para além dessas duas agremiaçôes, as diversas pesquisas históricas que ultimamente têm explorado o tema do protagonismo negro em Santa Catarina no período posterior à abolição da escravatura, mediante personagens, agenciamentos políticos, conexóes sociais, fluxos culturais e 
interlocuçóes raciais. Este artigo, portanto, tem o desiderato de fazer um balanço inicial dessa historiografia e, ao mesmo tempo, apontar as questóes, discutir os problemas e enfeixar os desafios dessa nova (e instigante) área de estudos e pesquisas.

\section{O negro no pós-abolição}

Em 1988, no centenário da abolição da escravatura no Brasil, foi publicado o livro Negro em terra de branco, no qual os autores faziam uma importante advertência: "são extremamente raras, e quase sempre pouco convincentes, as publicaçóes históricas e sociológicas que tratam da escravidáo e das re-

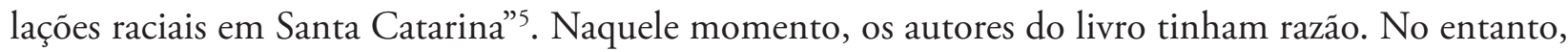
se era reduzido o número de pesquisas relacionadas à trajetória histórica do negro em Santa Catarina no período do cativeiro, o que dizer do período pós-aboliçáo? Durante um longo espaço de tempo, os historiadores apreenderam o negro como sinônimo de escravo, de modo que a história das experiências e vivências específicas desse segmento populacional ficou circunscrita ao período do cativeiro. Para o período imediatamente após a abolição, observava-se um fato curioso: os ex-escravos, libertos e seus descendentes desapareciam dos registros historiográficos, o que fez com que essa área temática fosse apropriada por sociólogos, antropólogos e folcloristas. Depois de décadas, esse quadro vem apresentando sinais de mudanças. $\mathrm{Na}$ atualidade, é crescente o número de historiadores que se dedicam a estudar a experiência histórica dos negros no período posterior à escravidão ${ }^{6}$.

Em Florianópolis, a primeira vez que esse tema apareceu no mundo acadêmico foi na pesquisa de Fernando Henrique Cardoso e Otavio Ianni, em 1960. Publicada como parte de um programa de investigação relacionada à sociedade escravocrata e ao negro no Brasil Meridional, a pesquisa foi produzida na esteira da chamada "Escola Paulista de Sociologia" . A preocupação dos autores foi de examinar as relações entre negros e brancos na capital catarinense, do século XVIII até o XX, conferindo uma atenção especial para o período do pós-abolição. A despeito de consultar fontes diversas ${ }^{8}$, apontar a violência das relaçóes escravistas e negar o mito da democracia racial, na versão catarinense 9 , eles viam o escravo como elemento insignificante para formação e desenvolvimento de Desterro (como se denominava Florianópolis até o século XIX) e territórios adjacentes. Como a colonização de Santa Catarina teria se efetivado, fundamentalmente, por interesses político-militares, não teria havido a utilização da mão de obra escrava em larga escala. Os poucos cativos existentes na regiáo teriam sido empregados na produção de subsistência, predominantemente no meio urbano e doméstico ${ }^{10}$.

Quando analisaram o pós-abolição, os jovens sociólogos ${ }^{11}$ notaram que o "preconceito de cor" não só existia, como era manifestado cotidianamente, contribuindo para a preservação da ordem escravocrata. Os negros eram alvo da discriminação racial e levavam desvantagem na estrutura socioeconômica em relação aos brancos, o que limitava suas chances de mobilidade social ${ }^{12}$. Uma vez que as condiçôes de existência material mantiveram-se relativamente estáveis desde o período da escravidão, a "população de cor" viu-se impedida de ascender na escala social em grande número. De acordo com os autores, houve tentativas de reagir a essa situação. A criação de "sociedades bailantes" é um exemplo disso. Antes mesmo do desfecho da escravidáo, os negros tinham as suas "sociedades dançantes e beneficentes". Com a abolição, elas se reorganizaram e adquiriram um novo caráter. Algumas foram extintas e outras foram criadas. Como as condiçôes de vida socioeconômica do grupo negro não melhoraram, não houve recursos para que essas sociedades pudessem manter-se. Por isso, seus efeitos, em termos de uma possível redefinição da imagem do negro, "não puderam fazer-se sentir de modo mais profundo". Por ocasião da realização da pesquisa de campo, em 1955, Fernando Henrique Cardoso e Otavio Ianni conheceram o "25 de Dezembro", um clube de negros, um dos mais bem organizados no meio negro de Florianópolis. Mantinha normas rígidas estabelecidas na década de 1930, quando foi fundado. Não aceitava brancos como sócios; apenas visitantes, os quais eram autorizados a fazer gastos no bar, mas não a dançar. Teria 
havido, ainda, tentativas de despertar entre os negros de Florianópolis a "consciência de raça", como pré-requisito para movimentos reivindicatórios. Entrementes, essas iniciativas não teriam encontrado apoio na "população de cor"13.

O fato é que o processo de integração racial na capital catarinense teria sido lento, quase nulo, até a década de 1930-40. Com o surto desenvolvimentista derivado da Segunda Guerra Mundial (19391945), novas oportunidades se abriram na rede comercial, industrial e de serviços. Os negros procuraram aproveitá-las, porém, nada que fosse muito animador, já que continuaram enfrentando dificuldades para conquistar melhores posições nas camadas mais baixas da sociedade. $\mathrm{Na}$ verdade, as portas da sociedade de classes não estavam totalmente fechadas, ainda que fosse difícil adentrá-las, pois isto envolveria a incorporação do negro à ideologia racial dos brancos e à renúncia de sua cultura afro-diaspórica. Em última instância, haveria uma única possibilidade de os negros se classificarem socialmente no pós-abolição: branqueando-se. "Branquear", afirma Ianni, "é uma aspiração universal. Negros, mulatos escuros e mulatos claros - todos querem branquear" em Florianópolis, não apenas no que dizia respeito à cor da pele, mas, em primeiro lugar, às condiçôes sociais que eles aspiravam ${ }^{14}$. O que os negros desejavam, portanto, era o "branqueamento social", na medida em que, em estado de alienaçáo, imitavam o branco na maneira de falar, de vestir e de se comportar. Ianni chama essa prática de "ideologia de compromisso", destinada a orientar o comportamento do "indivíduo de cor" no sentido de sua integração e ascensão sociais, ou seja, no sentido da sua "infiltração" em ambientes dominados por brancos ${ }^{15}$.

Em uma época fortemente marcada pelo discurso da inexistência do negro em Santa Catarina que se vangloriava de ser "uma Europa incrustada no Brasil"- e da "ausência" do racismo na sociedade brasileira, o estudo de Fernando Henrique Cardoso e Otavio Ianni teve o mérito de demonstrar que, ao contrário do que se propalava, o negro se fez presente no Brasil Meridional desde o período colonial, sendo o alvo predileto do racismo. Isto não significa que o estudo dos sociólogos não apresente alguns problemas. No que diz respeito à suposta insignificância quantitativa de escravos em Santa Catarina, os autores de Negro em terra de branco observaram que, embora os escravos nunca tenham sido a maioria da população da província, da Ilha, ou de Desterro, sua participação no conjunto da população não era, entretanto, desprezível: eles representavam "a quinta parte do contingente populacional até meados da década de 1850, sendo que, no caso de Desterro, chegou a atingir mais de 40\% em 1831 "16. Ultimamente, diversas pesquisas vêm indicando que, no tempo de vigência da escravidão, a presença negra em Santa Catarina não foi residual, tanto qualitativa quanto quantitativamente ${ }^{17}$. É verdade que a economia da província não se baseava em latifúndios com grandes plantéis de escravos, mas também é verdade que a mão de obra de origem africana não era, de modo algum, inexpressiva. Para a economia do litoral, Beatriz Gallotti Mamigonian argumenta que os escravos perfaziam "algo entre um quarto e um terço da população na primeira metade do século XIX" ${ }^{18}$. Diante de núcleos urbanos diminutos e áreas rurais ainda predominantes, a mão de obra escrava não poderia ter sido utilizada apenas na esfera urbana e doméstica. Em trabalho relativamente recente, Paulino de Jesus Francisco Cardoso ${ }^{19}$ é enfático ao afirmar que a população de origem africana foi importante para a dinamização da economia de Desterro e o desenvolvimento do Estado catarinense, desempenhando, para além de trabalhados domésticos, atividades mercantis e rurais, no artesanato, no comércio e na agricultura.

Quando abordam o pós-abolição, Fernando Henrique Cardoso e Otavio Ianni inferem que o racismo contra o negro foi uma herança da escravidão. Na medida em que se desenvolvesse em Florianópolis uma sociedade capitalista e moderna (urbana e industrial), aquele "mal" estaria fadado ao desaparecimento. Diversas pesquisas já demonstraram que o preconceito e a discriminação contra os negros tinham (e ainda têm) motivações que não se esgotam nas relaçôes escravistas. É equivocado, assim, estabelecer uma ligação causal direta entre as relaçôes raciais do pós-abolição e o passado escravista. $\mathrm{O}$ racismo não permaneceu intacto depois do regime de cativeiro, tendo sido ajustado e reajustado em dissonâncias, assumindo novas funçôes, vertentes e roupagens dentro da nova ordem. Definitivamente, a emergência de uma sociedade 
capitalista e moderna não garantiu o desaparecimento das desvantagens associadas à cor da pele. Como a história de outros grupos subordinados indica, aqueles que ocupam as posiçóes dominantes raramente se revelam inclinados a abrir mão de seus privilégios e aceitar uma ordem social mais justa como "simples" decorrência de ideais democráticos ${ }^{20}$.

Fernando Henrique Cardoso e Otavio Ianni até reconhecem os esforços dos negros no pós-abolição para atuarem em espaços próprios, como centros cívicos, clubes e bailes. Mas, apesar disso, os sociólogos entendem que os afro-catarinenses teriam se alienado e introjetado o "ideal de branqueamento", daí a aposta desses indivíduos no "refinamento das maneiras, na vida de família e na distinção social". Ora, por que pensar que esses padróes de comportamento social, político, cultural e moral eram prerrogativas exclusivas dos brancos? Estratos da população negra também podiam comportar-se como quaisquer outros cidadãos, investindo nas regras de boas maneiras, nos laços de família e nos símbolos de distinção social, sem necessariamente terem que abdicar de sua consciência racial. Ademais, Cardoso e Ianni não explicam quais seriam as posiçôes e posturas genuinamente afro-catarinenses no pós-abolição, e por uma razão "óbvia": elas teriam de ser inventadas ou retraduzidas, por meio de adaptaçóes, bricolagens e inovaçôes. Os afro-catarinenses não só reformularam práticas culturais, sociais, políticas e religiosas tradicionais (fossem de "negros" ou "brancos"), como formularam outras novas.

Depois de uma lacuna de décadas, o tema do negro no pós-abolição reapareceu na historiografia catarinense. Em 1997, Maria das Graças Maria realizou uma pesquisa enfocando os caminhos traçados pela população negra em Florianópolis, no período de 1930 e 1940, e apresentando aspectos de sua pluralidade de experiências sociais, culturais, recreativas, religiosas e identitárias ${ }^{21}$. As elites teriam implementado uma série de medidas visando à modernização da capital catarinense nas primeiras décadas do século XX. Com efeito, essas medidas modernizadoras não eram anódinas, posto que passavam por uma política de controle social e racial. Nesse contexto, as "populaçóes de origem africana" da cidade procuraram resistir, construindo seus próprios territórios, como as comunidades (da Coloninha, no Continente, e do Morro da Caixa D'água); os footings (pontos de encontro) da Praça XV, da Rua Arcipreste Paiva e da calçada do Palácio do Governo; as irmandades católicas (Nossa Senhora do Rosário e São Benedito dos Homens Pretos); os terreiros de culto afro-brasileiro (como o terreiro da Malvina) e os clubes (União Recreativa 25 de Dezembro, Brinca Quem Pode, Flor da Mocidade, Flor do Abacate, Tiramão). Segundo Graças Maria, os negros ocuparam, assim, os mais diversos rincóes da capital catarinense, desde os mais tradicionais (como a "cozinha", os "lavadouros públicos" e a "rua") até os de maior honorabilidade (como as "escolas públicas e particulares", as "sociedades recreativas", as "irmandades católicas" e a "Câmara de Vereadores e de Deputados"). Para tanto, fabricaram e refabricaram práticas, discursos e representaçôes, negociaram a identidade cultural e religiosa, articularam canais para decisões coletivas, selaram alianças com segmentos da sociedade civil e dialogaram com o poder público ${ }^{22}$.

Do ponto de vista do recorte espacial, as pesquisas, que tratam do tema do protagonismo negro em Santa Catarina no pós-abolição, não têm se restringido a Florianópolis; várias cidades do interior do Estado já foram objeto de estudos, neste sentido. Em 1999, Frank Nilton Marcon defendeu uma dissertação de mestrado na qual investigou a presença dos negros na cidade de Lages durante as primeiras décadas da República, verificando, nas práticas cotidianas, as "formas de resistência" articuladas por esse segmento populacional. Baseado no Recenseamento do Brasil em $1872^{23}$, o autor constatou que o número de "pardos" e "pretos" livres era três vezes maior do que o número de escravos e que, somando negros livres e escravos, eles representariam quase metade dos habitantes do Planalto Serrano - região compreendida pelas freguesias de Lages, Baguaes, Campos Novos, Curitibanos e São Joaquim. Esses dados são importantes porque evidenciam como o discurso das elites mascarou a presença negra no Planalto Serrano, na segunda metade do século $\mathrm{XX}^{24}$.

Com a abolição do regime do cativeiro, novos padrôes de civilidade e progresso germinaram em Lages. As palavras de ordem passaram a ser higienização, embelezamento, melhoramento urbano e 
modernização da cidade. Nesse quadro, os ex-escravos, libertos e seus descendentes foram socialmente repelidos (ou incluídos marginalmente), mas, mesmo assim, não sucumbiram e procuraram fazer valer a sua margem de autonomia, bem como o seu estilo próprio de vida, caracterizado pela versatilidade, pelos fluidos deslocamentos e pelas constantes reterritorializaçóes. Quando entravam em cena no espaço urbano, os novos personagens animavam sambas e batuques; patrocinavam fandangos, bailes e festas; praticavam uma religiosidade híbrida, em suma, defendiam direitos ou costumes tradicionais. Segundo Marcon, um capítulo ímpar da resistência negra em Lages foi o Centro Cívico Cruz e Souza, entidade recreativa, cívica e literária dos "homens de cor", fundada em 1918. A implantação desse Centro Cívico estaria relacionada ao desejo dos descendentes de africanos de conquistarem e estabelecerem um espaço independente, onde pudessem se reunir, divertir-se e confraternizar, compartilhando as esperanças da ampliação dos seus direitos e os sonhos de um mundo melhor. Um ano após a sua fundação, a entidade contava com 60 sócios contribuintes de uma mensalidade de $1 \$ 000$ réis. Suas primeiras reunióes ocorreram no prédio onde funcionava a Escola Noturna dos Amadores da Arte. Já os primeiros grandes bailes, solenidades e sessôes comemorativas aconteceram no Teatro Municipal da cidade. Dos seus eventos anuais, os mais celebrados eram o 13 de Maio, data da Abolição, e o 22 de Setembro, data da fundação do Centro Cívico Cruz e Souza, mas a entidade também rememorava algumas datas cívicas, quando atualizava o espírito patriótico e o ideário de inclusão do negro no seio da nacionalidade ${ }^{25}$. Em 1919, a agremiação publicou o jornal Cruz e Souza, no qual apresentava notícias sobre a vida social da cidade, veiculava a opiniáo de articulistas e, principalmente, pautava as questóes ligadas ao mundo da comunidade negra. $\mathrm{O}$ jornal, porém, teve duração efêmera, não passando de sua quinta edição ${ }^{26}$.

O Centro Cívico Cruz e Souza também foi o objeto da pesquisa de mestrado de Mirian Adriana Branco, defendida em 2002. Inserida na problemática do nacionalismo que emergiu no Brasil durante a Primeira República (1890-1930), a criação dessa agremiação estaria em sintonia com o projeto das elites de modernizar e civilizar o país. Sabe-se que o Centro Cívico Cruz e Souza recebeu o apoio de Caetano Vieira da Costa, jornalista, intelectual e importante político da cidade de Lages. Ligado ao teatro, às artes e à cultura, foi de sua autoria o hino do Centro Cívico, que preconizava a necessidade de "elevar a alma", "educar os costumes", "acumular virtudes", enfim, "civilizar-se". O gesto de Vieira da Costa não foi isolado. Na avaliação de Adriana Branco, as elites de Lages afiançaram o "grupo de negros interessados em criar uma associação, cujo principal objetivo era promover o levantamento moral, intelectual e social da população negra do município”. Ou seja, as elites teriam apoiado o Centro Cívico Cruz e Souza porque acreditavam que ele estava comprometido com a conscientização dos negros no sentido de que "para ser cidadão, para participar do desenvolvimento nacional, era necessário adquirir civilidade”27.

Além do Planalto Serrano, o Vale do Itajaí é outra regiấo do Estado de Santa Catarina cuja presença negra no pós-abolição tem sido documentada. Em 2001, José Bento Rosa da Silva defendeu uma tese de doutorado na qual analisava a história e a memória dos estivadores de Itajaí. Desde o início do Século XX, a cidade de Itajaí sofreu o impacto da modernidade que chegava por meio de seu porto. Local de desembarque dos imigrantes europeus que foram colonizar o Vale do Itajaí desde o final do Século XIX, o "porto natural" da pacata cidade tornou-se, a partir das reformas executadas em 1904, o símbolo da modernidade no litoral Norte catarinense. Não obstante, esta modernidade produziu tensões e contradiçóes. Uma delas foi o nascimento de uma cultura dos trabalhadores portuários, particularmente dos estivadores, na cidade de Itajaí. Categoria profissional com substantiva participação dos afro-catarinenses, os estivadores se notabilizaram pela capacidade de forjar novas formas de luta e organização coletiva, dialogando com a sociedade civil e com o poder público e arrostando as formas tradicionais de relacionamento entre patróes e empregados. Da "idade do ouro", nas primeiras décadas do século XX, até o golpe militar de 1964, que instaurou a ditadura no Brasil, a trajetória dos estivadores em Itajaí teria constituído um capítulo do protagonismo operário - e por que não dizer negro - em Santa Catarina. Em sua pesquisa, José Bento Rosa da Silva consultou uma grande variedade de fontes históricas: desde 
as produzidas pelos próprios trabalhadores (depoimentos de ex-ativistas e seus familiares; memórias; atas de reuniôes e assembleias das associaçóes de classe; panfletos; boletins e relatórios), passando por aquelas produzidas pela sociedade civil (jornais e fotografias), até as originadas no Estado (processos criminais, processos trabalhistas e documentos administrativos da Capitania dos Portos) ${ }^{28}$.

Ao lado de Lages e Itajaí, Criciúma é outra cidade do interior catarinense cujo tema do protagonismo negro no pós-aboliçáo vem suscitando o interesse dos historiadores ${ }^{29}$. Nela, em 1937, nasceu a Sociedade Recreativa Uniâo Operária, clube que vem se ressignificando ao longo do tempo e se constituindo um território autônomo de sociabilidade, cultura e lazer da população negra de Criciúma e região Sul de Santa Catarina. No início, as atividades sociais do clube se restringiam à festa, ao baile, ao futebol e ao carteado; tempos depois, ele se metamorfoseou em espaço de sociabilidade e defesa orgânica da cidadania, com palestras, ações educativas e eventos artístico-culturais.

\section{Algumas questóes...}

Depois desse breve comentário sobre alguns trabalhos acerca do negro em Santa Catarina no pósabolição, cabe agora levantar questôes, identificar os impasses e discutir os desafios dessa nova área de estudos e pesquisas. Um dos gêneros de pesquisa bastante promissor é o da biografia. Em 2001, Karla Leonora Dahse Nunes concluiu sua dissertação de mestrado na qual perscrutou alguns aspectos biográficos de Antonieta de Barros, uma das mulheres afro-catarinenses mais celebradas pelo movimento negro contemporâneo de Florianópolis. Para a sua pesquisa, a autora examinou as crônicas escritas pela biografada e, por meio delas, procurou cartografar os movimentos sociais, políticos, econômicos e culturais desenvolvidos no Brasil, sobretudo na década de 1930, e sua repercussão na capital de Santa Catarina. Antonieta de Barros nasceu em Florianópolis, no inverno de 1901. De família humilde, sua mãe, Catarina de Barros, era originária de Lages e trabalhava como lavadeira. Do seu pai, pouco se sabe, além do nome, Rodolfo de Barros, e do fato de náo tê-la registrado oficialmente. Cedo, Antonieta demonstrou interesse pelos estudos; todavia, as dificuldades financeiras lhe tolhiam o ânimo. Em 1921, formou-se na Escola Normal à base de muito sacrifício e de alguma ajuda pecuniária de um amigo da família, então constituída por mais três irmãos. Dali em diante, começou a granjear reconhecimento e prestígio e a circular junto às elites locais ${ }^{30}$. Primeiramente, como professora proprietária de uma pequena escola e, a partir de 1925, como primeira secretária da Liga do Magistério e integrante do Centro Catarinense de Letras, agremiaçáo que congregava nomes importantes da intelectualidade e da política catarinenses. Em 1929, começou a escrever na imprensa, publicando artigos nos jornais Folha Acadêmica e República. Foi colunista, também, de vários outros jornais - A Semana, A Pátria, Correio do Estado, O Idealista e O Estado -, todos editados em Florianópolis. Engajou-se na vida político-partidária, envolveu-se em várias articulaçôes, alianças e confabulaçóes, o que lhe permitiu ter sido eleita Deputada Estadual pelo Partido Liberal Catarinense (PLC), no pleito de 1934, logo após a Constituição Federal Brasileira ter garantido o direito de voto às mulheres. Antonieta de Barros foi a primeira mulher negra no estado de Santa Catarina e, tudo indica, no Brasil, que assumiu um cargo político dessa magnitude. Em 1937, publicou o livro Farrapos de idéias, reunindo parte das crônicas publicada nos jornais de Florianópolis. Assinando as crônicas (e o livro) com o pseudônimo "Maria da Ilha", Antonieta de Barros discorria, com sensibilidade, sobre temas como educação, civilidade, religiosidade, virtudes morais, éticas e cívicas, além de tratar de questóes relacionadas às relaçôes de gênero e à vida política e social dos agitados anos 1930, no Brasil e no mundo. Devido à implantação da ditadura do Estado Novo e à consequente dissoluçáo da Assembleia Legislativa em 1937, voltou a se dedicar à educação, tendo sido professora de Português e Psicologia no Colégio Coração de Jesus e diretora, tanto do Instituto de Educação Dias Velho, de 1944 a 1951, quanto do Colégio Catarinense. Nas primeiras eleições depois da redemocratização do país, em 1947, Antonieta de Barros não conseguiu se eleger, 
ficando como suplente na Assembléia Legislativa de Santa Catarina; contudo, no ano seguinte, acabou por ser empossada no cargo de Deputada Estadual; desta feita, pelo Partido Social Democrático (PSD). Seu prematuro falecimento, em 1952, em virtude de complicaçôes envolvendo um coma diabético, mereceu a atenção da imprensa e gerou comoção em Florianópolis.

Nunes realizou uma pesquisa profícua, tendo em vista que procurou tecer, dialeticamente, os múltiplos fios que ligavam Maria da Ilha ao seu contexto. Conforme postulam as tendências biográficas contemporâneas, deve-se pensar a interaçáo entre as trajetórias individuais examinadas e os contextos nos quais estas se realizaram como uma via de máo dupla, "sem cair nem no individualismo exacerbado (como nas biografias tradicionais, do tipo 'a vida dos grandes vultos'), nem na determinação estrutural estrita (como nas análises marxistas ortodoxas)" ${ }^{\text {'1 }}$. Sem idealizaçóes ou perspectivas heroicizantes, a pesquisadora catarinense discorreu sobre as escolhas, as ambiguidades e as contradiçóes de Maria da Ilha ${ }^{32}$. Entretanto, pouco - para não dizer quase nada - falou da dimensão pessoal de sua vida: relaçóes familiares, amizades, amores, veleidades. Além disso, o que talvez seja mais passível de crítica, embora tenha lançado luzes sobre diversas facetas da personagem - a Antonieta de Barros escritora, educadora e política -, não discutiu sua identidade racial. $\mathrm{Na}$ verdade, Nunes até analisa o "aparente silêncio" de Antonieta de Barros sobre a questão do negro, porém de forma superficial, de sorte que não é possível apreender os sentidos e significados que a protagonista conferia à sua origem afrodescendente, nem como ela lidava com as assimetrias raciais. Isto é problemático, pois as diversas identidades da estrutura existencial de Maria da Ilha náo eram dissociadas; pelo contrário, articulavam-se e decerto repercutiram, em menor ou maior medida, na sua vida, na sua maneira de pensar, sentir e agir.

Independentemente disso, cabe reconhecer que Antonieta de Barros rompeu com vários estereótipos (e tabus) relacionados à raça, classe e gênero, na medida em que conquistou mobilidade social, investiuse de símbolos de distinção, burlou várias barreiras do "preconceito de cor" e ousou desempenhar um papel de destaque no espaço público, numa época em que poucas mulheres o faziam. Talvez seja por isso que sua trajetória desperte tanto fascínio, entre negros e brancos ${ }^{33}$. Nunes argumenta que o fato de uma mulher negra ter adentrado no "difícil, quase inacessível, campo político numa época em que as oligarquias catarinenses revezavam-se no poder" e a política era vista como "coisa de homem", é algo extraordinário, "inédito" ${ }^{34}$. Sem dúvida. Para uma mulher afro-catarinense ter conseguido participar do mundo da "grande" política, na primeira metade do século XX, tratou-se de uma "proeza", mas será que não existiram outras Antonietas de Barros? Isto é, mulheres negras que, embora não tivessem se inserido nas altas estruturas do poder, politizaram o cotidiano, agenciaram a vida dinamicamente, pactuaram alianças orgânicas e engendraram mecanismos alternativos para decisões e açôes coletivas? Eis uma indagação que só pode ser plenamente respondida mediante novas pesquisas.

O fato é que Antonieta de Barros não foi a única pessoa de ascendência africana que se destacou no cenário da produção cultural e educacional de Santa Catarina. Pode-se mesmo supor o florescimento ali de uma intelectualidade negra na primeira metade do século XX. Ildefonso Juvenal da Silva, Trajano Margarida, João Rosa Júnior, Amália Efigênia da Silva, Maria da Rosa Lapa, Demerval Cordeiro dos Santos, Maria Carlita, Dorvalina Machado Coelho e Maria Venânia de Farias Martins são nomes de outros afrocatarinenses que exerceram atividades intelectuais nas mais diversas esferas - como professores, jornalistas, poetas, compositores, músicos, oradores -, participando de grêmios literários, escrevendo poesias, publicando artigos e livros. Suas biografias, no entanto, ainda estão à espera dos historiadores. Em 2007, Fábio Garcia publicou um opúsculo registrando a existência de intelectuais, músicos e poetas negros nas cidades de Florianópolis e Tijucas, desvelando algumas pistas dos itinerários traçados por João Rosa Júnior (18821932), Trajano Margarida (1889-1946) e Ildefonso Juvenal da Silva (1894-1965) $)^{35}$, considerados por ele como "os maiores expoentes negros" do panorama artístico-cultural da capital do Estado na década de $1910^{36}$. Têm-se dúvidas se esse julgamento superlativo tem respaldo nas evidências históricas; o certo é que a trajetória de muitos outros afro-catarinenses, "ilustres" ou "anônimos", precisa sair do limbo. 
Uma das questóes que vem sendo negligenciada pela historiografia diz respeito à diversidade racial (ou à presença negra) na história social do trabalho em Santa Catarina. A formação da classe operária foi um processo complexo, plural e multifacetado e que, no caso específico do Brasil, para o qual náo se deve ignorar a participação dos negros. A Sociedade Beneficente XV de Novembro - fundada em 15 de novembro de 1906 -, foi a primeira entidade organizada a defender os interesses dos trabalhadores na orla portuária de Itajaí. De acordo com José Bento Rosa da Silva, fizeram parte da fundaçáo ex-escravos e seus descendentes. Entre eles, destacaram-se Silvério Joaquim Ramos, o Tio Silvério (um ex-escravo), Sebastiáo Lucas Pereira (filho de escravos) e outros ${ }^{37}$. Em vez de alienados, despolitizados ou atrasados, setores dos descendentes de escravos e libertos desenvolveram uma consciência de classe e mesmo esposaram as hostes sindicais, sendo que alguns deles desempenharam mais do que papéis de figurantes nesse processo. Sebastiáo Lucas Pereira, em especial, chegou a presidir a Sociedade XV de Novembro. Oriundo de Espinheirinhos, na zona rural de Itajaí, mudou-se depois de casado para o meio urbano da cidade, ingressou na estiva e iniciou sua militância política. Pereira foi o primeiro afrodescendente a ocupar um cargo de dirigente dos trabalhadores portuários em Itajaí na primeira década do século XX. Numa região marcada por uma significativa presença de imigrantes europeus, não deve ter sido fácil um filho de escravos ser aceito como líder, ainda que do operariado, pois as tensóes étnicas fizeram parte da formação dos trabalhadores portuários em Itajai ${ }^{\bigotimes}$. De toda sorte, seu exemplo sugere que uma parcela dos afro-catarinenses não só foi protagonista da história social do trabalho, como ainda cumpriu um papel de relevância na construção do movimento operário.

$\mathrm{Na}$ década de 1920, duas outras associaçôes ligadas aos trabalhadores portuários foram erigidas: o Clube de Regatas Cruz e Sousa e o Humaitá Futebol Clube. Com fins exclusivamente recreativos, eram espaços voltados para as camadas populares e afro-descendentes, já que o Náutico Marcílio Dias e o Náutico Almirante Barroso eram clubes da elite e não permitiam o ingresso de negros, inclusive nos seus quadros futebolísticos. O "clube dos pretos" ou "time dos pretos", como ficaram popularmente conhecidos o Cruz e Sousa e o Humaitá, promoviam, além da prática desportiva, bailes e tardes dançantes. Por outro lado, a "linha de cor" se inscrevia até mesmo no interior do movimento operário. Sabe-se que a Sociedade Beneficente XV de Novembro animava bailes e tardes dançantes em sua sede com a presença de brancos e de negros, mas em dias alternados: num dia era o baile dos brancos e no outro, o dos negros ${ }^{39}$. A experiência histórica dos estivadores de Itajaí denota que uma fração dos afrocatarinenses militava, simultaneamente, em organizaçóes de recorte racial e sindical. Em Florianópolis, a militância dual igualmente existia: o caso de Epaminondas Vicente de Carvalho é um bom indicador disso. Formado no curso de carpintaria da Escola de Aprendizes Artífices, este negro presidiu, em 1921, a comissão de sindicância do Centro Cívico e Recreativo José Boiteux, importante agremiação dedicada aos "homens de cor"; em 1924, filiou-se à Liga Operária e Beneficente de Florianópolis, entidade da qual se tornou procurador em 1928; dois anos depois, também foi eleito procurador da União Beneficente e Recreativa Operária ${ }^{40}$. O desafio da historiografia na atualidade é, pois, compreender como Epaminondas Vicente de Carvalho e outros indivíduos articularam, de maneira combinada e flexível, uma consciência "negra" e "operária", estabelecendo conexôes entre as identidades raciais e classistas"

Já um tema que precisa ser aprofundado nessa nova área de estudos e pesquisa é o da própria militância negra, nas associações civis, nos clubes e nos jornais. Fernando Henrique Cardoso e Otavio Ianni fazem menção a alguns clubes fundados pelos afro-catarinenses em Florianópolis, como o 24 de Maio (que funcionou no princípio do século XX), o Grêmio da Mocidade (atuante em torno de 19101917) e a União Recreativa 25 de Dezembro, contudo não aprofundam a investigação. Cardoso argumenta que a "consciência de raça" no pós-abolição não resultou em mobilizaçáo política. Teria surgido uma efêmera articulação, na década de 1930, a favor da criação da Frente Negra Brasileira, porém não ela não encontrou apoio na "população de cor". Na concepçáo de Cardoso, não houve em Florianópolis "nenhum movimento que pretendesse reagir contra a discriminação racial, e que pudesse, 
dessa forma, interferir criticamente nas auto-avaliaçóes dos negros" ${ }^{2}$. Isto é, os afro-catarinenses até teriam criado uma "consciência de raça", mas de forma despolitizada, apática, anódina, sendo incapazes, assim, de impulsionar um movimento anti-racista, que colocasse em xeque as desigualdades entre negros e brancos.

Maria das Graças Maria discorda desse tipo de interpretaçáo. A ausência de um movimento negro organizado de caráter "explicitamente anti-racista", ao menos nas décadas de 1930 e 1940, não teria significado uma omissão dos afro-catarinenses face ao "preconceito de cor", mas, que suas formas de organização podem ter adquirido características peculiares. "A presença de territórios negros na cidade [de Florianópolis]", afirma a pesquisadora, "já serve como indício da não apatia dos diferentes grupos negros na definição dos espaços a serem ocupados por eles. O footing na Praça XV de Novembro e a

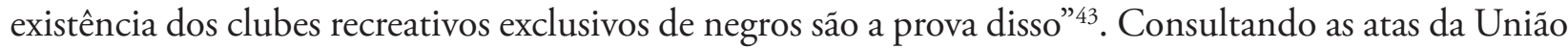
Recreativa 25 de Dezembro, Graças Maria rastreia aspectos da história desse clube negro, fundado em Florianópolis, no ano de 1933. Resposta à "linha de cor" que assolava várias casas da rede de lazer da cidade, o 25 de Dezembro apresentava uma estrutura administrativa organizada, com presidente, tesoureiro, diretoria feminina, regimento interno e estatutos. Sua existência exprimiu a conquista de um ponto de encontro, sociabilidade e confraternização da população negra; contudo, também desempenhou o papel de polo catalisador dos problemas, dos sonhos e das esperanças emancipatórias desse segmento populacional. A autora faz alusão à Sociedade Recreativa Brinca Quem Pode, outro importante clube negro de Florianópolis, fundado entre 1934 e 1935. Diferentemente da União Recreativa 25 de Dezembro, o Brinca Quem Pode não impedia o ingresso de pessoas brancas; no entanto, seus freqüentadores eram, em sua maioria, "pessoas de cor" ${ }^{\prime 4}$.

Para a segunda metade do século XX, Joselina da Silva, em sua tese de doutoramento, examina o percurso trilhado pela União Catarinense dos Homens de Cor (UCHC). Criada em Blumenau, em 1962, sob a liderança de Avandié Inácio de Souza - conhecido popularmente como o "Príncipe Negro" -, a agremiação manteve-se em atividade até os anos oitenta, animando congressos, palestras, conferências, campanhas educacionais, festas e concursos de beleza. Em 1967, a UCHC liderou a organização do Congresso do Negro, no Teatro Álvaro de Carvalho, em Florianópolis, no qual, entre outras autoridades presentes, encontrava-se o ex-governador do Estado, Ivo Silveira. A agremiação procurou solidificar o seu trabalho na sociedade local, mas não perdeu de vista a perspectiva afro-diaspórica. Com esse ímpeto, publicou o jornal $O$ Colored - cujo noticiário privilegiava o cotidiano dos negros no continente africano - e recepcionou as delegaçóes do Senegal (1965), da Nigéria (1980) e da República do Togo (1982), em três ocasióes distintas. No ano do centenário da Abolição, a agremiação comemorou seus vinte cinco anos de existência, com atividades que lhe deram visibilidade na imprensa de Blumenau. "Se observarmos com atenção", afirma Joselina da Silva

percebemos que a pronúncia da sigla UCHC é uchic. Assim Avandié de Oliveira passou a ser membro da "uchic", que contribuiu para atrair para o grupo os negros da cidade. Afinal era chic (elegante) ser membro da UCHC (pronúncia uchic). Posteriormente os membros do grupo começaram a denominar-se de uchiquianos e o nome do grupo passou a ser grafado com a letra i, transformando-se em UCHIC (União Cultural dos Homens de Cor do Interior e Capital). Esta foi, portanto, a segunda estratégia de atração. Construir uma identidade que além de racial, era também de classe ${ }^{45}$.

Já Claudia Mortari e Paulino de Jesus Cardoso fazem referência a dois grupos negros de Florianópolis: o Grupo Cultural Cruz e Souza, da década de 1960, e a Sociedade Cultural Antonieta de Barros, do final da década de 1970. O primeiro era presidido por Osvaldo Silveira e se reunia no saláo da antiga União Operária (UBRO), para discutir os problemas da população negra da cidade. Nada se sabe acerca de seu fim. O segundo grupo era coordenado por Osvaldo Silveira e comprometeu-se com a denúncia pública do racismo e as novas formas de luta em defesa do negro. 
Em 20 de novembro de 1980, seus ativistas organizaram o primeiro ato público em comemoração ao Dia Nacional de Consciência Negra em Santa Catarina. Em uma "articulação com os partidos políticos de oposiçáo ao regime [militar], com o Diretório Central dos Estudantes - DCE/ UFSC, entre outras entidades, denunciaram as múltiplas faces do racismo e a discriminação racial. Este ato teve uma grande repercussão na imprensa catarinense" ${ }^{46}$. Em que pesem os louváveis esforços de Maria das Graças Maria, Joselina da Silva, Claudia Mortari e Paulino de Jesus Cardoso, seus trabalhos não discutem (ou sistematizam) uma série de questôes, de modo que são necessárias pesquisas mais verticalizadas e meticulosas para documentar as formas articuladas (e não articuladas) da insurgência contra o "preconceito de cor", bem como dissecar a emergência das associaçôes negras em Santa Catarina no pós-abolição, quer as de caráter recreativo e cultural, quer as mais recentes, de cunho cívico e político ${ }^{47}$.

Uma das lacunas dessa nova área de estudos e pesquisas diz respeito ao papel feminino na história do protagonismo negro. Como as afro-catarinenses atribuíram sentidos e significados à vida no pósabolição e negociaram os marcadores de raça e gênero ${ }^{48}$ Mesmo vivendo numa sociedade marcada pela dominação masculina e pela subordinação feminina, fraçôes das "mulheres de cor" procuraram se afirmar, arquitetar espaços próprios e governar a sua agência. Maria das Graças Maria assinala que as mulheres negras não desempenharam apenas papéis coadjuvantes na vida de Florianópolis nas décadas de 1930 e 1940. Criativas e versáteis, atuaram em múltiplas áreas - no mercado de trabalho formal e informal, no campo educacional, na esfera política, no mundo das letras e das artes -, exercendo diferentes profissóes, como professoras, escritoras, secretárias de clubes, operárias do setor têxtil, costureiras, bordadeiras e empregadas domésticas. Entretanto, quem eram essas criaturas, em termos de discursos, práticas e cosmovisóes? Nem Graças Maria nem qualquer outro autor aborda densamente a trajetória dessas afro-catarinenses ${ }^{49}$. Não basta saber, em tese, que as mulheres negras pelejaram para conquistar espaços de autonomia, foram (ou tentaram ser) protagonistas de sua história ou cumpriram um papel proativo no cenário da cidade. É chegada a hora de retirar as personagens afro-catarinenses dos porôes do esquecimento, observando as especificidades que envolveram o protagonismo dessas mulheres. Mais ainda. É chegada a hora de procurar entender como as relaçôes de gênero na sociedade foram atravessadas pelo recorte racial e, por outro lado, perceber como se deram as relaçóes de gênero no meio negro.

No terreno educacional, o protagonismo negro emergiu vivamente no pós-abolição. Para se contrapor ao analfabetismo, à falta de oportunidades educacionais e ao "preconceito de cor" no sistema escolar, um setor dos afro-catarinenses investiu em iniciativas pedagógicas próprias, oferecendo cursos de alfabetizaçáo, ou mesmo criando estabelecimentos de ensino voltados para a "população de cor". $\mathrm{Na}$ cidade de Joinville, os "libertos de 13 de maio" criaram um clube com a denominação Instrução e Beneficência, em 1889. Seu fito era difundir a "instrução primária entre os associados, havendo para isso uma escola noturna" ${ }^{50}$. Em Lages, o Centro Cívico Cruz e Souza, criado em 1918, patrocinava sessóes de leituras e mantinha uma biblioteca em sua sede, pois se acreditava que o livro era um dos instrumentos mais eficazes para elevar o cabedal cultural de seus associados ${ }^{51}$. Mais tarde, nasceu ali a preocupação com a alfabetização dos jovens e adultos negros. Já em Florianópolis, o Centro Cívico e Recreativo José Boiteux abriu a escola Cruz e Sousa, por volta de 1920. Infelizmente, pouco se sabe da experiência histórica dessa unidade de ensino, a não ser que funcionava à noite, em condiçóes precárias e que os intelectuais afro-catarinenses, Ildefonso Juvenal da Silva e Trajano Margarida, foram dois de seus professores. Este último acumulava uma experiência docente, posto que ministrara um curso particular de "instrução" na cidade de Itajaí, entre os anos de 1908 a 1910 Barros, por sua vez, costumava exaltar a educação em suas crônicas publicadas na imprensa na década de 1930: "A grandeza da vida, a magnitude da vida gira em torno da educação do homem, isto é, no adestramento do homem, que deve integrar-se na sociedade, como valor positivo". E concluía: "Sem 
a educação precisa, capaz, eficiente, o homem falha à sua destinação". Em outra crônica, Maria da Ilha era mais incisiva:

Toda ação requer instrumento. E o instrumento máximo da vida é a instrução. [...] Só a instrução, só o livro, elevando o homem, lhe dá o direito de ser homem; só a instrução consciente rouba as criaturas ao servilismo aviltante e procura alçá-las às cumiadas, onde o ar é puro e donde se descortinam todos os panoramas maravilhosos. Daí a necessidade de se tornarem os moços aptos para a luta grandiosa que os espera, daí a necessidade de se ver a Escola, dentro da sua soberba e excepcional finalidade. ${ }^{53}$

Como é possível notar, a educação era considerada como a verdadeira redenção. Seria por meio dela que o indivíduo prosperaria cultural e socialmente, adquirindo dignidade, respeito e reconhecimento da sociedade. A despeito desses indícios, novas investigaçóes precisam ser desenvolvidas para saber: por que os afro-catarinenses depositavam tanta esperança no poder redentor da educação? Como transcorreram as experiências educacionais das escolas para negros em Santa Catarina no pós-abolição, em relação aos períodos de funcionamento, à estrutura física, aos recursos pedagógicos, à clientela, ao perfil dos professores, ao rendimento dos alunos etc.? Novas sondagens precisam ser realizadas para descortinar as múltiplas dimensôes e os diferentes significados do ativismo afro-catarinense na educação, seja na capital, ou no interior.

No circuito do Atlântico Negro, as populações da diáspora africana se caracterizaram pelas relaçóes de trocas e empréstimos de ideias, comportamentos, referenciais, símbolos e artefatos político-culturais. Os pontos ou nós que compóem esse circuito não se organizam em uma sequência teleológica, em direção a um destino comum. Eles sugerem disjunçóes entre as formas de agenciamento micro-político exercido nas culturas e movimentos de resistência e de transformação e outros processos políticos que são visíveis em escala maior. "Juntas", afirma Paul Gilroy, essa "pluralidade, regionalidade e ligação transversa promovem algo mais que uma condição adiada de lamentação social diante das rupturas do exílio, da perda, da brutalidade”. Formas contrastantes de ação político-cultural brotaram e ensejaram novas possibilidades através das quais os povos da diáspora africana reconheceram que os efeitos do deslocamento espacial tornaram a questáo da origem algo bastante complexo. Eles podem mesmo "ter chegado a aceitar a possibilidade de que não são mais o que já foram um dia, e não podem, portanto, rebobinar as fitas de suas caóticas histórias culturais" ${ }^{24}$.

Os afro-brasileiros participaram do circuito do Atlântico Negro no período do pós-abolição, na medida em que se mantiveram conectados, por meio de viagens, deslocamentos e reterritorializaçóes, com a experiência histórica e cultural dos afro-descendentes da América do Norte, do Caribe e da Europa. José Bento Rosa da Silva relata as venturas e desventuras de Firmino Alfredo Rosa. Nascido em Itajaí, em 1891, este afro-catarinense foi marinheiro da Companhia de Navegação Lloyd Brasileiro, quando viajou aos Estados Unidos e à Europa. No exterior, entrou em contato com a doutrina "marxista-leninista" recém vitoriosa na União Soviética. Tornou-se então socialista e, de volta ao Brasil, abraçou as lides sindicais. Em sua vida de ativista, participou da fundaçáo da Associação dos Marítimos no Rio de Janeiro; dos Estivadores de São Francisco do Sul (SC) e participou da reunião de criação do Partido Comunista Brasileiro (PCB), no Rio de Janeiro, em 1922. Já em Itajaí, tomou parte na fundação da Alliança Beneficente dos Trabalhadores em Trapiches e Armazéns, em 1929. Associação dissidente da Sociedade Beneficente XV de Novembro, nela Rosa ocupou o cargo de Presidente. Na avaliação de Bento da Silva, esse afro-catarinense era o elo entre os estivadores de Itajaí e o cenário político nacional. Por meio de sua militância nos grandes centros, como Santos (SP) e Rio de Janeiro (a então capital federal), os trabalhadores de Itajaí se atualizavam, tomando conhecimento dos últimos acontecimentos políticos e das recentes discussôes sindicais. Firmino Alfredo Rosa seria, portanto, "um dos que faziam a mediaçáo entre as organizaçóes dos trabalhadores dos grandes centros e Itajaí, São Francisco do Sul e outras cidades portuárias do litoral do Estado de Santa Catarina" 55 . No que concerne às questôes raciais, desde cedo Rosa adquiriu consciência do "problema do negro", não obstante foi graças à viagem ao exterior que, possivelmente, essa consciência se intensificou. 
Participou, também, da fundação do Clube de Regatas Cruz e Sousa e, em 1922, quando lhe foi recusado candidatar-se a uma vaga na Marinha de Guerra do Brasil por ser negro, protestou, denunciando o fato publicamente no jornal O Pharol.

Dionísio Veiga foi outro afro-catarinense influenciado pela experiência político-cultural do Atlântico Negro. Analogamente, foi um "marinheiro-de-linha-de-fora", condição que lhe deu a oportunidade de viajar para o exterior. Registrou em seu diário de bordo que esteve nos Estados Unidos em 1918, tendo antes, entretanto, passado pelas ilhas de Barbados, Martinica e Mont Serrat, na região do Caribe. Em solo yankee, sentiu na pele o drama da "linha de cor". Ao entrar numa barbearia, teria sido discriminado e insultado. Foi a experiência de viagem por essa rede de comunicação afro-diaspórica que, talvez, tenha despertado (ou aguçado) sua consciência racial. Paralelamente à sua identidade negra, Dionísio Veiga assumiu uma identidade de classe. Na primeira diretoria da Sociedade Beneficente dos Estivadores, ocupou o cargo de secretário, até que, na década de 1930, alcançou a presidência da entidade. Nesse mesmo período, foi um dos fundadores do Círculo Operário de Itajaí. Militou em organizaçôes partidárias e, devido à sua seriedade, tinha bom trânsito no meio político ${ }^{56}$.

O circuito do Atlântico Negro não foi ativado apenas em âmbito externo. No Brasil, as populaçôes da diáspora africana, de diversas regióes, estados e cidades, comunicaram-se, influenciaram-se mutuamente, numa rede de troca de ideias, discursos e práticas políticas, sociais, culturais e religiosas. E como se operou o complexo intercâmbio afro-diaspórico em Santa Catarina no pós-abolição? Mesmo longe de respostas definitivas, já é possível entrever alguns indícios desse processo, por intermédio de personagens, episódios, narrativas e cenários específicos. Júlio Dantas de Oliveira - um negro que foi presidente da Sociedade Uniāo Beneficente dos Estivadores de Itajaí, na década de 1930, permanecendo no cargo por cerca de quinze anos - era proveniente de Olinda, em Pernambuco (portanto, era conhecido pela alcunha de Pernambuco). Com sete anos, teria se transferido para o Rio de Janeiro e, ulteriormente, radicado-se em Itajaí. Carismático, tinha a fama de ser um exímio orador, de modo que seus discursos emocionavam as plateias. Apesar de semianalfabeto, desfrutava de forte liderança na categoria, e de prestígio no meio político do Estado, destacando-se o então governador Jorge Lacerda ${ }^{57}$. Os exemplos de diálogos inter e transregionais afro-brasileiros se estendem. Comenta-se que a escola de samba Protegidos da Princesa foi fundada graças à presença de um grupo de marinheiros cariocas em Florianópolis que, saudosos do carnaval de sua terra natal, teriam se somado aos negros locais e criado, em 1948, a primeira escola de samba da capital catarinense. Entre os idealizadores da União Recreativa 25 de Dezembro - um dos mais organizado clubes de negros de Florianópolis -, em 1933, encontrava-se Tertuliano Fernandes, morador do bairro Agronômico e procedente do estado do Paraná ${ }^{\bigotimes}$. Então, de que maneira, com quais dimensões e em que medida os afro-catarinenses interagiram - influenciaram e foram influenciados na elaboração e reelaboração das práticas, dos discursos e das representaçóes - com negros de outras partes do país? Deveras importante, essa questáo demanda ser investigada pelos historiadores na atualidade ${ }^{59}$.

Que sejam esboçadas novas abordagens para o estudo do protagonismo negro no pós-abolição, colocando em xeque os paradigmas antigos, redimensionando as interpretaçóes cristalizadas, dilatando as possibilidades de investigação, propondo novos problemas e repensando o debate. Quanto às fontes a serem examinadas, as opçôes são abundantes, para não dizer inexauríveis. Cumpre ao historiador, contudo, ser criativo, paciente e determinado, consultando (ou revisitando) as fontes tradicionais (desde aquelas produzidas pelo Estado, aos documentos cartoriais, judiciais e eclesiásticos; dos periódicos aos memorialistas) e as fontes menos convencionais (orais, musicais, literárias, fílmicas e iconográficas) ${ }^{60}$.

Com a entrada de milhares de imigrantes europeus ao longo da segunda metade do século XIX e o paulatino alijamento (ou reterritorização) do negro do sistema ocupacional, as elites catarinenses esperavam consubstanciar o tão sonhado projeto de branqueamento da população do Estado. Por 
essa perspectiva, a "solução imigrantista" não deve ser vista apenas como uma resposta ao problema demográfico ou de "falta de braços", uma vez que ela integrou um projeto de modernizaçáo no longo prazo, através do qual "o branqueamento da população era altamente desejado" ${ }^{61}$. Partindo do princípio de que a superioridade racial do europeu era inconteste, forjou-se um imaginário que associava o branco ao progresso e à civilização, ao passo que o negro e o mestiço eram associados à inferioridade e à degeneração racial, sendo considerados, por conseguinte, grandes estorvos ao desenvolvimento nacional. No limiar do século XX, as elites catarinenses ainda bebiam nesse caldo de cultura e não esqueciam o sonho de tornar Florianópolis uma cidade europeia: clara, bela, moderna e higienizada. Com esse espírito, buscaram apagar tudo que lembrasse a escravidão, instalando os serviços de bondes, água, esgoto, realizando os aterros e demoliçôes e combatendo os antigos territórios populares. Locais como "a Tronqueira (atual Artista Bittencourt), Figueira (na Conselheiro Mafra), Toca (Rua São Martinho), Beco do Sujo (Hercílio Luz) foram sendo eliminados"62. Na conjuntura do pós-abolição, os descendentes de africanos continuavam sendo preteridos socialmente e vistos como símbolo do atraso e a encarnação dos males (como o ócio, a vagabundagem, a ignorância, o vício etc.) que assolavam a sociedade ${ }^{63}$. Isto náo significa dizer que as relaçóes raciais, das quais resultaram a dominação do branco e a subordinação do negro, foram estabelecidas aprioristicamente. Sua formatação foi um processo longo e paradoxal. Não foi, seguramente, uma imposição natural ou expressão da inevitabilidade histórica, mas antes o produto dos imprevisíveis embates travados por indivíduos de carne e osso, no cotidiano. Embates travados em torno das concepçóes de trabalho, raça, cidadania e liberdade ${ }^{64}$.

Ao examinar o negro no pós-abolição, deve-se verificar o movimento, a interação entre as continuidades e as transformações; a relação entre a memória de práticas e experiências vividas concretamente e suas atualizações em novas paisagens sociais que exigiram novas respostas e significados. Então, "o território negro", assevera Ilka Boaventura Leite, aparece "como o elemento de visibilidade a ser resgatado. Através dele, os negros, isolados pelo preconceito racial, procuraram reconstruir uma tradiçáo centrada no parentesco, na religião, na terra e nos valores morais cultivados ao longo de sua descendência" ${ }^{\text {. }}$. Mesmo vivendo em condiçôes desfavoráveis na "Europa incrustada no Brasil", os afro-catarinenses não capitularam e procuraram elaborar e reelaborar seus próprios mecanismos de sociabilidade, política, cultura e lazer, a partir de distintas racionalidades, lógicas e possibilidades. Criativos e versáteis, apropriaram-se seletivamente da retórica da cidadania, tentaram tirar vantagens dos interstícios do sistema racial e batalharam por ampliar posiçóes de liderança. Para tanto, dialogaram com segmentos da sociedade civil e do Estado, costuraram alianças circunstanciais e negociaram questôes diversas, sem, contudo abdicarem da capacidade de pugnar por sua autodeterminaçáo. É chegado o momento, portanto, de considerar o negro como o principal protagonista de sua história e, ao mesmo tempo, como sujeito histórico que contribuiu para a produção de narrativas, cenários e enredos na história de Santa Catarina, ora diretamente, ora transversalmente. Negro no pós-abolição, eis um tema complexo e fugidio, que tem despertado cada vez mais a atenção da sociedade civil, do mundo acadêmico, da mídia e da agenda política nacional. Os desafios, todavia, dessa nova área de estudos e pesquisas não são poucos. Longe das determinaçôes exógenas, os negros no pós-abolição devem ser apreendidos de forma endógena, a partir de seus próprios termos. Operando num campo de possibilidades e incertezas, sua experiência histórica caracterizou-se pelo "fazer-se", pela ressignificação e cruzamento de códigos culturais diversos - particularmente do legado afro-diaspórico e dos valores ditos "brancos" -, pela (re)edição de tradiçóes e crenças múltiplas, de tramas e urdiduras descontínuas e heterogêneas.

Nessas narrativas capilares, cumpre decifrar como os negros percebiam os contextos específicos nos quais se inseriam, e de que forma procuraram tirar proveito deles para se autoafirmarem e ampliarem seus direitos como cidadãos. Neste sentido, a agência afro-catarinense revestiu-se de um significado especial, merecendo cadeira cativa nas investigaçôes vindouras. Isto não significa olvidar que a "agência 
requer uma fundamentação, mas não requer que a base dessa fundamentação seja totalizada; requer movimento e manobra, mas não requer uma temporalidade de continuidade ou acumulação; requer direção e fechamento contingente, mas nenhuma teleologia e holismo" ${ }^{66}$. A agência afro-catarinense caracterizou-se por seu caráter fragmentado e descentrado, assim como por sua vocação plástica, mutante e provisória, engendrada em cada contingência histórica. Para estudar o negro no pós-abolição, recomenda-se, igualmente, desconsiderar as abordagens essencialistas das identidades e culturas negras. Em vez de fixas, naturalizadas e congeladas, as identidades e culturas dos indivíduos são construções dinâmicas, relacionais, fluidas e concatenadas em cada situação específica. Os negros articularam identidades plurais, estabeleceram fronteiras étnicas móveis e transigiram formas culturais híbridas. Não param aqui os desafios dessa nova área de estudos e pesquisas, de modo que se deve surpreender os afrocatarinenses pelo prisma de suas tradiçôes, acomodaçóes e ambivalências, atentando para os diferentes sentidos e significados que eles conferiram à sua maneira de ser, pensar e agir.

No que concerne à história do protagonismo negro no pós-abolição, ainda há muito a ser burilado, documentado, cotejado e escrito. São muitas as dúvidas e poucas as certezas. Uma delas é a de que os afro-catarinenses assumiram o governo de seu destino e pelejaram para cumprir um papel proativo e construtivo no Brasil Meridional. Quando formulou o conceito de história "vista de baixo", E. P. Thompson advertiu acerca da necessidade de conceber os membros das classes inferiores como agentes cujas açóes afetaram, em maior ou menor grau, o mundo em que viviam. As pessoas comuns não eram apenas "um dos problemas com que o governo tinha de lidar" ${ }^{67}$. De modo semelhante, faz-se mister reconhecer que os afro-catarinenses, malgrado viverem em condiçôes sociais subalternas, foram capazes de influenciar a "roda da fortuna", criar (e recriar) um mundo para si; por isso foram atores históricos, muito mais do que um "problema" que as elites tiveram que enfrentar.

\section{Notas}

${ }^{1}$ Cf. GARCIA, Fábio. Negras pretensóes: a presença de intelectuais, músicos e poetas negros nos jornais de Florianópolis e Tijucas no início do século XX. Florianópolis: Umbutu, 2007, p. 51.

${ }^{2}$ Disputando com os nomes dos abolicionistas José do Patrocínio e André Rebouças, o poeta negro João da Cruz e Souza foi a figura escolhida como patrono do Centro Cívico. Nascido na cidade de Nossa Senhora do Desterro, hoje Florianópolis, em 1861, era filho de Guilherme, um escravo, e Carolina Eva da Conceição, uma forra. Graças à ajuda do Marechal Guilherme Xavier de Sousa, estudou nas melhores instituiçóes de ensino, época em que revelou seu pendor literário. Com o tempo, transferiu-se para o Rio de Janeiro, onde se projetou no mundo das letras. Considerado o inaugurador (e principal expoente) da poesia simbolista no Brasil, teve sua vida marcada pela incompreensão, pelas barreiras da cor e pelas constantes dificuldades financeiras. Faleceu em Minas Gerais, em 1898. A respeito de Cruz e Souza, ver MURICI, Andrade. Atualidade de Cruz e Sousa. In: SOUSA, Cruz e. Obra completa. Organizaçáo e introdução de Andrade Murici. Rio de Janeiro: Nova Aguilar, 2000.

${ }^{3}$ Quanto ao suposto pioneirismo da Associação dos Homens de Cor ou do Centro Cívico Cruz e Souza na história do associativismo negro em Santa Catarina no pós-abolição, não há consenso entre os especialistas. Claudia Mortari e Paulino de Jesus Cardoso sustentam que a Sociedade 13 de Maio, fundada no município de Itajaí em 1906, foi a primeira agremiação negra de que se tem notícia no Estado (Cf. MORTARI, Claudia; CARDOSO, Paulino de Jesus. Territórios negros em Florianópolis no século XX. In: BRANCHER, Ana (Org.). História de Santa Catarina: estudos contemporâneos. Florianópolis: Letras Contemporâneas, 1999, p. 93). Essa afirmação, porém, deve ser relativizada, pois há indícios de terem surgido agremiaçóes do gênero desde o final do século XIX. Arselle de Andrade da Fontoura e Janine Gomes da Silva, por exemplo, identificaram a existência do clube Instrução e Beneficência, agremiação de negros criado na cidade de Joinville, em 1889, um ano depois da abolição da escravatura. Cf. FONTOURA, Arselle de Andrade; SILVA, Janine Gomes da. A presença negra em Joinville durante o século XIX. Série Pensamento Negro em Educação, NEN, Florianópolis, vol. 9, 2006, p. 49.

${ }^{4} \mathrm{O}$ relato de fundação do Centro Cívico Cruz e Souza baseou-se em MARCON, Frank Nilton. Visibilidade e resistência negra em Lages (1888-1918). Dissertação (Mestrado em História) - Programa de Pós-graduação em História, Universidade do Vale do Rio dos Sinos, São Leopoldo, 1999; e BRANCO, Mirian Adriana. Corpos nefastos - cidadania incerta. Em Lages, o Centro Cívico Cruz e Souza e a invenção da nação. Dissertação (Mestrado em História) - Programa de Pós-graduação em 
"UM DESEJO INFINITO DE VENCER": O PROTAGONISMO NEGRO NO PÓS-ABOLIÇẤO

Petrônio Domingues

História, Universidade Federal de Santa Catarina, Florianópolis, 2002.

${ }^{5}$ Cf. PEDRO, Joana Maria et al. Negro em terra de branco: escravidão e preconceito em Santa Catarina no século XIX. Porto Alegre: Mercado Aberto, 1988, p. 62.

${ }^{6}$ Ver CUNHA, Olívia Maria Gomes da; GOMES, Flávio dos Santos. Quase-cidadão: histórias e antropologias da pós-emancipação no Brasil. Rio de Janeiro: Editora FGV, 2007.

${ }^{7}$ A partir de meados da década de 1950, um grupo de cientistas sociais e jovens pesquisadores (Roger Bastide, Florestan Fernandes, Fernando Henrique Cardoso, Otavio Ianni, Renato Jardim Moreira, entre outros), da Universidade de São Paulo, desenvolveram estudos sobre as relaçóes raciais no Brasil a partir de uma perspectiva analítica nova: a das desigualdades e das discriminaçóes raciais, relacionadas à modernização e à situação das classes sociais no país. A esse grupo de pesquisadores convencionou-se chamar de "Escola Paulista de Sociologia".

${ }^{8}$ Eis as fontes consultadas por Fernando Henrique Cardoso e Otavio Ianni para a reconstrução do passado: jornais, documentos oficiais da Câmara e da Presidência da Província (correspondência, atas das sessóes, entre outros), relatórios e discursos dos Presidentes da Província, levantamentos estatísticos e censos demográficos, relatos de viajantes e cronistas. Quanto às fontes utilizadas para a caracterização da situação de contato inter-racial, durante a pesquisa, foram as seguintes: entrevistas, relatos e depoimentos, histórias de clubes, associaçóes e instituições, descriçóes de bailes, observação da população de cor e questionário aplicado à população do ensino médio.

9 "É preciso ressaltar", assinala Cardoso, "que a violência, a repressão e a coerção apontadas como as principais formas do controle social do comportamento do escravo noutras áreas do Brasil encontravam[-se] igualmente”, em Florianópolis, "seja a exercida pelos senhores, seja a exercida pelas autoridades policiais". Cf. CARDOSO, Fernando Henrique; IANNI, Otavio. Cor e mobilidade social em Florianópolis: aspectos das relaçóes entre negros e brancos numa comunidade do Brasil Meridional. São Paulo: Editora Nacional, 1960, p. 133.

${ }^{10}$ Em mais de uma vez, Fernando Henrique Cardoso é enfático ao argumentar que o "escravo negro" constituiu "um coeficiente relativamente pequeno" da população de Santa Catarina: "por causa do pouco desenvolvimento econômico da área no período colonial e nos primeiros cinqüenta anos da Independência, não emergiu nenhum setor importante de produção onde fosse compensadora a inversão de capitais na mão-de-obra escrava". Como o "escravo negro" era em número irrelevante, teria cumprido "um papel muito reduzido na atividade econômica de Santa Catarina". Cf. CARDOSO, Fernando Henrique; IANNI, Otavio. Cor e mobilidade social em Florianópolis, op. cit., p. 10.

${ }^{11}$ Quando a pesquisa foi realizada em Florianópolis, em julho de 1955, Fernando Henrique Cardoso tinha 24 anos e, Otavio Ianni, por volta de 28.

12 "Mostramos", concluem os autores, "como a discriminação racial operava rigorosamente com relação aos negros e seus descendentes mestiços, tanto sob a forma de discriminação econômica como social ou legal”. Cf. CARDOSO, Fernando Henrique; IANNI, Otavio. Cor e mobilidade social em Florianópolis, op. cit., p. 235.

${ }^{13}$ Idem, ibidem, p. 139.

${ }^{14}$ Idem, ibidem, p. 183.

${ }^{15}$ Idem, ibidem, p. 226.

${ }^{16}$ Cf. PEDRO, Joana Maria et al. Negro em terra de branco, op. cit., p. 19. Fernando Henrique Cardoso e Otavio Ianni não foram os únicos intelectuais a subestimar a importância, inclusive numérica, dos negros em Santa Catarina. Vale a pena consultar, nesse sentido, os trabalhos de Patrícia Freitas (O Instituto Histórico e Geográfico de Santa Catarina: espaço de saber "qualificado". Esboços, Revista do Programa de Pós-graduação em História da UFSC, Florianópolis, v. 4, n. 4, 1996, p. 9-21; Margem da palavra, silêncio do número: o negro na historiografia de Santa Catarina. Dissertação (Mestrado em História) - Programa de Pós-graduação em História, Universidade Federal de Santa Catarina, Florianópolis, 1997), que realizou uma pesquisa sobre a forma como os intelectuais do Instituto Histórico e Geográfico do Estado trataram a questáo do negro. Considerando os escritos produzidos por dois de seus integrantes, Oswaldo Rodrigues Cabral e Walter Fernando Piazza, a autora revela como o discurso histórico oficial procurou minimizar, quando não obliterar, a importância dos afro-descendentes na formação de Santa Catarina.

${ }^{17}$ Para Frank Nilton Marcon, "o fato de a historiografia tradicional do estado ter identificado um número menor de escravos em relação a outras províncias no período Imperial, não é argumento suficiente para associarmos que tais números correspondessem a toda a população negra da região, pois faz-se necessário reconhecermos que houve um significativo número de descendentes de africanos livres ou libertos em Santa Catarina”. Cf. MARCON, Frank Nilton. Visibilidade e resistência negra em Lages (1888-1918), op. cit., p. 5.

${ }^{18}$ Cf. MAMIGONIAN, Beatriz Gallotti. Africanos em Santa Catarina: escravidão e identidade étnica (1750-1850). In: FRAGOSO, João Luis Ribeiro; FLORENTINO, Manolo Garcia; SAMPAIO, Antonio Carlos Jucá; CAMPOS, Adriana Pereira (Orgs.). Nas rotas do império: eixos mercantis, tráfico e relaçóes sociais no mundo português. Lisboa: Instituto de Investigaçóes Científicas Tropicais; Vitória: EDUFES, 2006, p. 609-644. 
${ }^{19}$ Ver CARDOSO, Paulino de Jesus Francisco. Negros em Desterro: experiências de populaçóes de origem africana em Florianópolis, 1860-1888. Tese (Doutorado em História) - Programa de Pós-graduação em História, Pontifícia Universidade Católica, São Paulo, 2004.

${ }^{20}$ Ver HASENBALG, Carlos Alfredo. Discriminaçâo e desigualdades raciais no Brasil. Rio de Janeiro: Graal, 1979; e TELLES, Edward. Racismo à brasileira: uma nova perspectiva sociológica. Rio de Janeiro: Relume Dumará, 2003.

${ }^{21}$ Maria das Graças Maria já havia apresentado os resultados parciais de sua pesquisa em artigo publicado em 1995 . Ver MARIA, Maria das Graças. Memória subterrânea: construção das representaçôes de identidade do negro em Florianópolis. Esboços, Revista do Programa de Pós-graduação em História da UFSC, Florianópolis, vol. 2, n. 2, 1995, p. 58-69.

${ }^{22}$ Cf. MARIA, Maria das Graças. Imagens invisiveis de Áfricas presentes: experiência das populaçóes negras no cotidiano da cidade de Florianópolis (1930-1940). Dissertação (Mestrado em História) - Programa de Pós-graduação em História, Universidade Federal de Santa Catarina, Florianópolis, 1997. José Ribeiro dos Santos, por exemplo, dirigente do clube de negros Brinca Quem Pode, teria laços de amizade com o governador Nereu Ramos, fato que proporcionava prestígio social a ele e ao clube. Segundo a autora, a presença do governador "no clube era freqüente, principalmente nos bailes de gala. [...] O Chefe do Executivo era presidente do Partido Liberal, que era o mesmo partido de José Ribeiro dos Santos, presidente do Clube. As relaçóes entre o governador e o Clube eram muito amistosas. Isso pode ser evidenciado nas falas de algumas pessoas que representavam aquela entidade”. Cf. MARIA, Maria das Graças. Imagens invisiveis de Áfricas presentes, op. cit., p. 154 e 204.

${ }^{23}$ Disponível em <http://biblioteca.ibge.gov.br> [Nota do Editor].

${ }^{24}$ Cf. MARCON, Frank Nilton. Visibilidade e resistência negra em Lages (1888-1918), op. cit., p. 19-20.

${ }^{25}$ Como pondera Marcon, a fundação de uma sociedade para os "homens de cor" em Lages "fora imbuída pelo caráter cívico, por ocorrer num momento em que o civismo estava latente no meio intelectual, no meio das elites, e até mesmo entre alguns setores populares. A comemoração e exaltação de datas cívicas pelos descendentes de africanos demonstrara o seu desejo de participar ativamente de um novo projeto de nação e inserirem-se como sujeitos históricos desse processo, como parte do seu todo. A percepção, por parte dos negros, de que a Abolição da Escravatura e a constituição republicana não os colocara efetivamente em igualdade de oportunidades econômicas e sociais em relaçáo aos outros elementos nacionais, por carregarem o estigma da inferioridade racial, amadurecera progressivamente, durante as primeiras décadas da República, o sentimento de alteridade em relação a outros grupos sociais". Cf. MARCON, Frank Nilton. Visibilidade e resistência negra em Lages (1888-1918), op. cit., p. 135.

${ }^{26}$ Idem, p. 146.

${ }^{27}$ Cf. BRANCO, Mirian Adriana. Corpos nefastos - cidadania incerta. Em Lages, o Centro Cívico Cruz e Souza e a invenção da nação. Dissertação (Mestrado em História) - Programa de Pós-graduação em História, Universidade Federal de Santa Catarina, Florianópolis, 2002, p. 17 e 32.

${ }^{28}$ Ver SILVA, José Bento Rosa da. Do porão ao convés: estivadores de Itajaí (SC) - entre a memória e a história. Tese (Doutorado em História) - Programa de Pós-graduação em História, Universidade Federal de Pernambuco, Recife, 2001.

${ }^{29}$ Em 2009, Júlio César Rosa iniciou seu mestrado em História, na Universidade do Estado de Santa Catarina (UDESC), com o projeto de pesquisa intitulado Resistência e territorialidade: a construção de clubes e associaçóes de afrodescendentes no Sul de Santa Catarina nos anos de 1930 a 1970.

30 "Estrategicamente", afirma Nunes, "Antonieta de Barros não apenas circulou, mas aliou-se ao que tudo indica, aos mais proeminentes nomes das oligarquias catarinenses não os confrontando. Pelo contrário, aspirando e reproduzindo os ideais de uma elite burguesa [...]. Como uma estrategista mesmo, evidenciando muita competência, soube jogar, articular, manejar habilmente as peças daquele imenso tabuleiro chamado 'vida' e conseguiu sobreviver ardilosa, não só ao seu tempo e à sua história, mas ao nosso tempo também, marcando com a sua trajetória as páginas da História Catarinense”. Cf. NUNES, Karla Leonora Dahse. Antonieta de Barros: uma história. Dissertação (Mestrado em História) - Programa de Pós-graduação em História, Universidade Federal de Santa Catarina, Florianópolis, 2001, p. 58.

${ }^{31}$ Ver SCHIMDT, Benito Bisso. A biografia histórica: o "retorno” do gênero e a noção de “contexto”. In: GUAZELLI, César Augusto Barcelos et al. Questóes de teoria e metodologia da História. Porto Alegre: Editora da UFRGS, 2000, p. 121-129.

32 "Nossa trajetória pessoal na vida”, afirma Nunes, "implica escolhas, quando nos decidimos por uma, imediatamente estamos renunciando outras noventa e nove. Talvez o segredo esteja em náo lamentar as perdas e possibilidades das noventa e nove que deixamos para trás e assumir os riscos de nossa escolha. Antonieta [de Barros] escolheu aliar-se ao poder e assumiu-o, por certo estava ciente de sua decisão. Assim, se traçou um objetivo para sua vida e se este estava ligado à ideia de destacar-se, atingiu-o plenamente". Por isso, pondera a autora em outro momento, Maria da Ilha não conseguiu "manter-se fiel às suas convicçôes e às suas origens. Quando talvez tenha pressentido que seus ideais pessoais lhe escapavam, era tarde demais para revê-los, pois a morte já estava à espreita”. Cf. NUNES, Karla Leonora Dahse. Antonieta de Barros: uma história, op. cit., p. 59 e 140.

${ }^{33}$ Em 1987, o Grêmio Recreativo e Cultural Escola de Samba Acadêmicos do Samba prestou uma homenagem a Antonieta de Barros, fazendo de sua história tema do desfile carnavalesco daquele ano. Em 2001, comemorou-se o centenário de seu 
nascimento. Proposto pela então deputada Ideli Salvatti, o evento caracterizou-se por discursos apologéticos e sacralizadores de Maria da Ilha, de modo que o movimento negro catarinense resolveu elegê-la como heroína. Em seu trabalho, Karla Nunes relata um fato interessante. Para comemorar (ou marcar) o final do século XX, "o grupo RBS (Rede Brasil Sul, empresa que coordena atividades de comunicação em rádio, jornais e televisão) em parceria com a Telesc Brasil Telecom (empresa de telefonia) lançou um concurso para homenagear os nomes que 'ajudaram a construir a história de Santa Catarina'; por este, a população do Estado deveria eleger os 'Vinte Catarinenses Que Marcaram o Século XX'. Era uma lista extensa composta por cinqüenta nomes selecionados pelos pesquisadores Celestino e Sérgio Sachet, dentre os quais, o de Antonieta de Barros. Segundo nota do jornal Diário Catarinense, mais de um milhão de pessoas participaram da escolha. Figuraram nomes de empresários, esportistas, religiosos, educadores, artesãos, entre outros. Antonieta de Barros foi uma das vinte personalidades que marcaram, senão o século, pelo menos a vida, a lembrança ou a curiosidade dos que a elegeram”. Cf. NUNES, Karla Leonora Dahse. Antonieta de Barros: uma história, op. cit., p. 70-71.

${ }^{34}$ Idem, p. 9.

35 João Rosa Júnior foi maestro, regendo diversas bandas musicais, militares e civis, tanto em Santa Catarina quanto no Rio Grande do Sul. Quando o glaucoma agravou-se e ele perdeu a visão, por volta de 1920, Rosa Júnior fixou residência em Florianópolis. Consta, a partir dessa fase, sua dedicação ao ofício literário e à publicação de livros. Trajano Margarida e Ildefonso Juvenal da Silva, por seu turno, formaram "parceria em diferentes momentos de suas trajetórias profissionais. Juntos inauguraram a Associação dos Homens de Cor, em 1915, o Centro Cívico e Recreativo José Boiteux em 1920 e o Centro Catarinense de Letras, em 1925. Ainda no ano de 1915, Trajano Margarida apareceu como colaborador no jornal literário Folha Rosea, de propriedade de Ildefonso Juvenal. Além das instituiçóes fundadas, ambos editaram, entre 1914-19, livros poéticos, peças teatrais e de história”. Cf. GARCIA, Fábio. Negras pretensóes: a presença de intelectuais, músicos e poetas negros nos jornais de Florianópolis e Tijucas no início do século XX. Florianópolis: Umbutu, 2007, p. 16-17. Uma curiosidade: Ildefonso Juvenal - que fez carreira na Força Pública, sendo nomeado 2a. Tenente da corporação, em 1923 - foi informante, em 1955, da pesquisa de Fernando Henrique Cardoso e Otavio Ianni, da qual resultou a publicação do livro Cor e mobilidade social em Florianópolis. Como forma de gratidão, os sociólogos lhe dirigiram as seguintes palavras na "Introdução" do livro: "Agradecemos a colaboração sempre muito pronta e eficiente do grupo que investigamos, para o qual esperamos que este trabalho possa ter alguma valia”. Cf. CARDOSO, Fernando Henrique; IANNI, Otavio. Cor e mobilidade social em Florianópolis, op. cit., p. XL.

${ }^{36}$ Cf. GARCIA, Fábio. Negras pretensóes, op. cit., p. 15.

${ }^{37}$ Ver SILVA, José Bento Rosa da. Do porão ao convés: estivadores de Itajaí (SC) - entre a memória e a história. Tese (Doutorado em História) - Programa de Pós-graduação em História, Universidade Federal de Pernambuco, Recife, 2001.

${ }^{38}$ Idem.

39 “Tanto o Cruz e Sousa quanto o Humaitá foram extintos nos anos trinta, ficando os afrodescendentes de Itajaí órfãos de um território negro, de interaçáo social, até a década de cinqüenta, quando novamente os trabalhadores portuários (estivadores), em sua maioria afrodescendentes, fundaram a Sociedade Cultural e Beneficente Sebastiáo Lucas, que permanece até os dias atuais, agora aberta a todos os segmentos étnicos, embora com a maior presença dos afrodescendentes”. Cf. SILVA, José Bento Rosa da. Do porão ao convés, op. cit., p. 105.

${ }^{40}$ Cf. GARCIA, Fábio. Negras pretensóes, op. cit., p. 40.

41 "Análises cruzadas de relaçóes raciais, étnicas e de classe”, salientava Silvia Hunold em 1998, "permitem redimensionar as abordagens tradicionalmente empreendidas por historiadores e cientistas sociais, propóem novas questóes, problematizam paradigmas explicativos e levam à investigação em novas fontes ou mesmo à releitura de fontes já utilizadas anteriormente". Cf. LARA, Silvia Hunold. "Blowin' in the wind": E. P. Thompson e a experiência negra no Brasil. Projeto História, São Paulo, n. 12,1995 , p. 36.

${ }^{42}$ Cf. CARDOSO, Fernando Henrique; IANNI, Otavio. Cor e mobilidade social em Florianópolis, op. cit., p. 139-140.

${ }^{43}$ Cf. MARIA, Maria das Graças. Imagens invisiveis de Áfricas presentes, op. cit., p. 170.

${ }^{44}$ Idem, p. 65-66 e 195.

${ }^{45}$ Ver SILVA, Joselina da. União dos Homens de Cor (UHC): uma rede do movimento social negro, após o Estado Novo. Tese (Doutorado em Ciências Sociais) - Programa de Pós-graduação em Ciências Sociais, Universidade do Estado do Rio de Janeiro, Rio de Janeiro, 2005.

${ }^{46}$ Cf. MORTARI, Claudia; CARDOSO, Paulino de Jesus. Territórios negros em Florianópolis no século XX, op. cit., p. $97-100$.

${ }^{47}$ Quando Karine Pereira Goss empreendeu, entre 2001 e 2003, uma pesquisa sobre as trajetórias dos ativistas do Núcleo de Estudos Negros (NEN) - organização anti-racista criada em Florianópolis na década de 1980 -, ela observou que "praticamente náo havia bibliografia sobre o movimento negro em Florianópolis”. Cf. GOSS, Karine Pereira. Trajetórias militantes em uma organização do movimento negro de Florianópolis (SC). Série Pensamento Negro em Educação, NEN, Florianópolis, vol. 9, 2006, p. 145. Se, por um lado, não é possível concordar totalmente com o diagnóstico de Goss, por outro, vale regis- 
trar que, durante décadas, predominou o silêncio historiográfico em torno do tema da resistência negra em Santa Catarina no pós-abolição. Ao se perguntar sobre os caminhos (e descaminhos) palmilhados pela sociedade 24 de Maio, pelo Grêmio da Mocidade, de 1910; pela Associação dos Homens de Cor, de 1915; pelo Centro Cívico e Recreativo José Boiteux, de 1920, e pela sucursal da União dos Homens de Cor, não se tem ainda respostas qualificadas. Isto para mencionar apenas algumas agremiaçóes da capital na primeira metade do século XX, pois, se abrangêssemos as agências afro-brasileiras de todo o Estado, ao longo de todas as décadas do pós-abolição, esse número se multiplicaria.

${ }^{48}$ Uma das informantes de Maria das Graças Maria alega que, nos primeiros anos das escolas de samba em Florianópolis, as mulheres negras eram proibidas de desfilarem, barreira que só foi quebrada em 1952. Cf. MARIA, Maria das Graças. Imagens invisiveis de Áfricas presentes, op. cit., p. 161.

${ }^{49}$ É escusado dizer que Antonieta de Barros é uma retumbante exceção, pois os trabalhos de Josefina da Silva (Antonieta de Barros - Maria da Ilha: discurso e catequese. Dissertação (Mestrado em Teoria Literária) - Programa de Pós-graduação em Teoria Literária, Universidade Federal de Santa Catarina, Florianópolis, 1991), Maria das Graças Maria (Imagens invisiveis de Áfricas presentes, op. cit.) e Karla Leonora Dahse Nunes (Antonieta de Barros: uma história, op. cit.) exploram, direta ou transversalmente, o itinerário dessa personagem. Mas o registro histórico de uma única afro-catarinense é pouco. Urge, portanto, pesquisar outras mulheres negras, sejam elas "ilustres" (como foi o caso de "Maria da Ilha"), sejam elas anônimas, procedentes de Florianópolis, ou das cidades do interior.

${ }^{50}$ Cf. FONTOURA, Arselle de Andrade; SILVA, Janine Gomes da. A presença negra em Joinville durante o século XIX. Série Pensamento Negro em Educação, NEN, Florianópolis, vol. 9, 2006, p. 49.

${ }^{51}$ Ver BRANCO, Mirian Adriana. Corpos nefastos - cidadania incerta, op. cit.

${ }^{52}$ Ver LINHARES, Juventino. O que a memória guardou. Itajaí: Ed. Univali, 1997.

${ }^{53}$ Cf. ILHA, Maria da [Antonieta de Barros]. Farrapos de ideias. 3.ed. Florianópolis: Imprensa Oficial do Estado de Santa Catarina, 2001 [1937], p. 159, 162 e 203. Como já comentado, Antonieta de Barros foi professora da rede de ensino de Florianópolis. Isto permite supor a presença de mulheres negras no magistério catarinense nas primeiras décadas do século XX? Talvez. Pelo menos para o período coevo, essa suposiçáo vem ganhando força. Em pesquisa de 2006, Elizabete Paulina Gomes procurou reconstituir a trajetória discente e docente de quatro mulheres negras - Osvaldina da Rosa Vieira, Maria Eulália de Freitas Silva, Valdeonira Silva dos Anjos e Maria de Lourdes Costa Gonzaga -, pela via da história oral. Nascidas em Florianópolis entre 1927 e 1938, essas mulheres ingressaram no magistério nas décadas de cinquenta e sessenta, "em escolas isoladas, passando pelas reunidas e encerrando em grupos escolares”. Mais do que apontar aspectos da infância, da formação primária e secundária, do casamento, da família e do lazer de quatro mulheres negras, a autora almeja demonstrar a efetiva participação desse segmento populacional na "construção da história da educação em Florianópolis". Ver GOMES, Elizabete Paulina. Professoras primárias: a construção profissional de alfabetizadoras negras em Florianópolis (1950-1970). Dissertação (Mestrado em Educação) - Programa de Pós-graduação em Educação, Universidade Federal de Santa Catarina, Florianópolis, 2006.

${ }^{54}$ Cf. GILROY, Paul. O Atlântico negro: modernidade e dupla consciência. São Paulo: Editora 34, 2001, p. 20.

${ }^{55}$ Cf. SILVA, José Bento Rosa da. Do porão ao convés, op. cit.

56 Idem.

${ }^{57}$ Idem.

${ }^{58}$ Cf. MARIA, Maria das Graças. Imagens invisiveis de Áfricas presentes, op. cit., p. 157 e 178.

${ }^{59}$ A título de exemplo, seria interessante investigar como a criação do Movimento Negro Unificado (MNU) em São Paulo, em 1978, com sua proposta afrocêntrica de afirmaçáo cultural e identitária, foi difundida, apropriada e reapropriada pela mobilização racial em Santa Catarina.

${ }^{60}$ Os documentos iconográficos permitiram a Maria das Graças Maria surpreender as populaçôes negras em Florianópolis, no seu cotidiano, nos vestígios da sua cultura afro-diaspórica, nas suas relaçóes de poder e de gênero. "As fotografias", argumenta Maria "auxiliaram na promoção da visibilidade dessas populaçôes, pelo registro histórico inegável da presença e das experiências vividas”. Cf. MARIA, Maria das Graças. Memória subterrânea: construção das representaçóes de identidade do negro em Florianópolis, op. cit., p. 22.

${ }^{61}$ Cf. PEDRO, Joana Maria et al. Negro em terra de branco, op. cit., p. 56; e PEDRO, Joana Maria et al. Escravidão e preconceito em Santa Catarina: história e historiografia. In: LEITE, Ilka Boaventura (Org.). Negros no Sul do Brasil: invisibilidade e territorialidade. Florianópolis: Letras Contemporâneas, 1996, p. 240.

${ }^{62}$ Cf. MORTARI, Claudia; CARDOSO, Paulino de Jesus. Territórios negros em Florianópolis no século XX, op. cit., p. 92.

${ }^{63}$ Se é verdade que desde a abolição da escravatura, em 1888, e a proclamação da República, em 1889, todos os brasileiros passaram a ser considerados iguais perante a lei, com os direitos republicanos garantidos, náo é menos verdade que os indivíduos, nas relaçôes sociais, políticas e culturais concretas, eram avaliados e classificados com base na sua cor. "O que se vai perceber no período é que, para as populaçóes de origem africana, as oportunidades de sobrevivência, principalmente 
no espaço urbano, tornaram-se cada vez mais difíceis". CfPEDRO, Joana Maria et al. Escravidão e preconceito em Santa Catarina: história e historiografia, op. cit., p. 242.

${ }^{64}$ Ver COOPER, Frederick; HOLT, Thomas C.; SCOTT, Rebecca J. Além da escravidão: investigaçóes sobre raça, trabalho e cidadania em sociedades pós-emancipação. Rio de Janeiro: Civilização Brasileira, 2005.

${ }^{65}$ Ver LEITE, Ilka Boaventura. Descendentes de africanos em Santa Catarina: invisibilidade histórica e segregação. In: (Org.). Negros no Sul do Brasil: invisibilidade e territorialidade. Florianópolis: Letras Contemporâneas, 1996, p. 50.

${ }^{66}$ Cf. BHABHA, Homi K. O local da cultura. Belo Horizonte: Ed. UFMG, 1998, p. 257.

${ }^{67}$ Ver THOMPSON, Edward P. As peculiaridades dos ingleses e outros artigos. Orgs. Antonio Luigi Negro e Sergio Silva. Campinas, SP: Editora da Unicamp, 2001.

\section{Referências bibliográficas}

BHABHA, Homi K. O local da cultura. Belo Horizonte: Ed. UFMG, 1998.

BRANCO, Mirian Adriana. Corpos nefastos - cidadania incerta. Em Lages, o Centro Cívico Cruz e Souza e a invenção da nação. Dissertação (Mestrado em História) - Programa de Pós-graduação em História, Universidade Federal de Santa Catarina, Florianópolis, 2002.

CARDOSO, Fernando Henrique; IANNI, Otavio. Cor e mobilidade social em Florianópolis: aspectos das relaçóes entre negros e brancos numa comunidade do Brasil Meridional. São Paulo: Editora Nacional, 1960.

CARDOSO, Paulino de Jesus Francisco. Negros em Desterro: experiências de populaçóes de origem africana em Florianópolis, 1860-1888. Tese (Doutorado em História) - Programa de Pós-graduação em História, Pontifícia Universidade Católica, São Paulo, 2004.

COOPER, Frederick; HOLT, Thomas C.; SCOTT, Rebecca J. Além da escravidão: investigaçôes sobre raça, trabalho e cidadania em sociedades pós-emancipação. Rio de Janeiro: Civilização Brasileira, 2005.

CUNHA, Olívia Maria Gomes da; GOMES, Flávio dos Santos. Quase-cidadão: histórias e antropologias da pós-emancipação no Brasil. Rio de Janeiro: Editora FGV, 2007.

FLORES, Maria Bernardete Ramos. Tecnologia e estética do racismo: ciência e arte na política da beleza. Chapecó: Argos, 2007.

FONTOURA, Arselle de Andrade; SILVA, Janine Gomes da. A presença negra em Joinville durante o século XIX. Série Pensamento Negro em Educação, NEN, Florianópolis, vol. 9, 2006, p. 47-58.

FREITAS, Patrícia. O Instituto Histórico e Geográfico de Santa Catarina: espaço de saber "qualificado”. Esboços, Revista do Programa de Pós-graduação em História da UFSC, Florianópolis, v. 4, n. 4, 1996, p. 9-21.

- Margem da palavra, silêncio do número: o negro na historiografia de Santa Catarina. Dissertação (Mestrado em História) - Programa de Pós-graduação em História, Universidade Federal de Santa Catarina, Florianópolis, 1997.

GARCIA, Fábio. Negras pretensôes: a presença de intelectuais, músicos e poetas negros nos jornais de Florianópolis e Tijucas no início do século XX. Florianópolis: Umbutu, 2007.

GILROY, Paul. O Atlântico negro: modernidade e dupla consciência. São Paulo: Editora 34, 2001.

GOMES, Elizabete Paulina. Professoras primárias: a construção profissional de alfabetizadoras negras em Florianópolis (1950-1970). Dissertação (Mestrado em Educação) - Programa de Pós-graduação em Educação, Universidade Federal de Santa Catarina, Florianópolis, 2006. 
GOSS, Karine Pereira. Trajetórias militantes em uma organização do movimento negro de Florianópolis (SC). Série Pensamento Negro em Educação, NEN, Florianópolis, vol. 9, 2006, p. 139-195.

HASENBALG, Carlos Alfredo. Discriminaçâo e desigualdades raciais no Brasil. Rio de Janeiro: Graal, 1979.

ILHA, Maria da [Antonieta de Barros]. Farrapos de ideias. 3.ed. Florianópolis: Imprensa Oficial do Estado de Santa Catarina, 2001 [1937].

LARA, Silvia Hunold. "Blowin' in the wind": E. P. Thompson e a experiência negra no Brasil. Projeto História, São Paulo, n. 12, 1995, p. 43-56.

Escravidão, cidadania e história do trabalho no Brasil. Projeto História, São Paulo, n. 16, 1998, p. 25-38.

LEITE, Ilka Boaventura. Descendentes de africanos em Santa Catarina: invisibilidade histórica e segregação. In: (Org.). Negros no Sul do Brasil: invisibilidade e territorialidade. Florianópolis: Letras Contemporâneas, 1996, p. 33-53.

LEUCHTENBERGER, Rafaela. Historiografia do trabalho em Santa Catarina: novas perspectivas. Esboços, Revista do Programa de Pós-graduação em História da UFSC, Florianópolis, v. 14, n. 18, 2007, p. $105-128$.

LINHARES, Juventino. O que a memória guardou. Itajaí: Ed. Univali, 1997.

MAMIGONIAN, Beatriz Gallotti. Africanos em Santa Catarina: escravidão e identidade étnica (17501850). In: FRAGOSO, João Luis Ribeiro; FLORENTINO, Manolo Garcia; SAMPAIO, Antonio Carlos Jucá; CAMPOS, Adriana Pereira (Orgs.). Nas rotas do império: eixos mercantis, tráfico e relaçôes sociais no mundo português. Lisboa: Instituto de Investigaçôes Científicas Tropicais; Vitória: EDUFES, 2006, p. 609-644.

MARCON, Frank Nilton. Visibilidade e resistência negra em Lages (1888-1918). Dissertação (Mestrado em História) - Programa de Pós-graduação em História, Universidade do Vale do Rio dos Sinos, São Leopoldo, 1999.

MARIA, Maria das Graças. Memória subterrânea: construção das representaçôes de identidade do negro em Florianópolis. Esboços, Revista do Programa de Pós-graduação em História da UFSC, Florianópolis, vol. 2, n. 2, 1995, p. 58-69.

Imagens invisiveis de Áfricas presentes: experiência das populaçóes negras no cotidiano da cidade de Florianópolis (1930-1940). Dissertação (Mestrado em História) - Programa de Pós-graduação em História, Universidade Federal de Santa Catarina, Florianópolis, 1997.

MORTARI, Claudia; CARDOSO, Paulino de Jesus. Territórios negros em Florianópolis no século XX. In: BRANCHER, Ana (Org.). História de Santa Catarina: estudos contemporâneos. Florianópolis: Letras Contemporâneas, 1999, p. 83-101.

MURICI, Andrade. Atualidade de Cruz e Sousa. In: SOUSA, Cruz e. Obra completa. Organização e introdução de Andrade Murici. Rio de Janeiro: Nova Aguilar, 2000.

NUNES, Karla Leonora Dahse. Antonieta de Barros: uma história. Dissertação (Mestrado em História) - Programa de Pós-graduação em História, Universidade Federal de Santa Catarina, Florianópolis, 2001.

PEDRO, Joana Maria et al. Negro em terra de branco: escravidão e preconceito em Santa Catarina no século XIX. Porto Alegre: Mercado Aberto, 1988. (Série Documenta - SC; 2). 
Escravidão e preconceito em Santa Catarina: história e historiografia. In: LEITE, Ilka Boaventura (Org.). Negros no Sul do Brasil: invisibilidade e territorialidade. Florianópolis: Letras Contemporâneas, 1996, p. 229-245.

SCHIMDT, Benito Bisso. A biografia histórica: o "retorno" do gênero e a noção de "contexto". In: GUAZELLI, César Augusto Barcelos et al. Questôes de teoria e metodologia da História. Porto Alegre: Editora da UFRGS, 2000, p. 121-129.

SILVA, José Bento Rosa da. Do porão ao convés: estivadores de Itajaí (SC) - entre a memória e a história. Tese (Doutorado em História) - Programa de Pós-graduação em História, Universidade Federal de Pernambuco, Recife, 2001.

SILVA, Joselina da. União dos Homens de Cor (UHC): uma rede do movimento social negro, após o Estado Novo. Tese (Doutorado em Ciências Sociais) - Programa de Pós-graduação em Ciências Sociais, Universidade do Estado do Rio de Janeiro, Rio de Janeiro, 2005.

SILVA, Josefina da. Antonieta de Barros - Maria da Ilha: discurso e catequese. Dissertação (Mestrado em Teoria Literária) - Programa de Pós-graduação em Teoria Literária, Universidade Federal de Santa Catarina, Florianópolis, 1991.

TELLES, Edward. Racismo à brasileira: uma nova perspectiva sociológica. Rio de Janeiro: Relume Dumará, 2003.

THOMPSON, Edward P. Costumes em comum: estudos sobre a cultura popular tradicional. São Paulo: Companhia das Letras, 1998.

. As peculiaridades dos ingleses e outros artigos. Orgs. Antonio Luigi Negro e Sergio Silva.

Campinas, SP: Editora da Unicamp, 2001. 